\title{
ADMINISTRATION OF A REGULATORY SMALL LOAN LAW
}

\author{
JAMES M. SULLIVAN*
}

In the United States, it is the inherent right of the individual to lend money, subject to certain restraints imposed by the usury laws and other general statutes. These restraints, however, provied ineffective in preventing deceit, excessive charges, and harsh collection practices in the small loan field. Recognition of these abuses and of the fact that small loans to borrowers, who lack readily negotiable collateral, cannot be made at the limited rates allowed by the usury laws had led most states to enact special statutes to govern the small loan field. These statutes do not limit the right of the individual to lend money at the rates allowed by the usury laws, but they give the privilege of charging a higher rate to licensees who submit to certain requirements designed for the protection of borrowers.

The granting of special privileges and the imposition of special restrictions in regulatory small loan laws has been sustained as a proper exercise of the police power. The statutory requirements imposed upon lenders licensed under small loan laws are more specific and stringent than those imposed by almost any other regulatory statute. Nevertheless, the effectiveness of these laws is highly dependent upon the adequacy of their administration which in turn depends upon the skill, initiative and understanding of the supervising official. Under the New Jersey Small Loan Act the Commissioner of Banking and Insurance is charged with its supervision and, under his direction, these powers are exercised by the Division of Personal Loan Agencies, a unit within the banking bureau.

The administration of regulatory small loan laws is a broad topic. This article will be confined to a brief description of the history of the New Jersey Small Loan Law and to a discussion of four important administrative problems: (I) licensing of applicants; (2) enforcement of the law as applied to licensees; (3) enforcement of the law as applied to non-licensees; (4) protection of the interests and welfare of the borrower in accordance with the spirit and intent of the law. The writer's close contact with the matters discussed makes frequent use of the first person unavoidable.

\section{History of the New Jersey Law.}

The enactment of a law placing the business of making loans of $\$ 300$ or less at greater rates of interest than $6 \%$ per annum under regulation in New Jersey was the

- Chief, Division of Personal Loan Agencies, Bureau of Banking, New Jersey State Department of Banking and Insurance. 
result of efforts of chambers of commerce, church and civic interests in the North Jersey industrial areas where lending of small sums was attended by sharp and unethical practices and extortionate charges. Our original act, written by Mr. Arthur Ham, then director of the Remedial Loan Department of the Russell Sage Foundation, was passed in March, 19r4. Like other laws of its kind, it was devoid of discretionary power. Its purpose was to attract capital, under regulation, to engage in the business. The statute required merely that applicants be of good character, that they file a bond of $\$ \mathrm{r}, 000$ and remit the license fee of $\$ 50$. Meeting these conditions, no person could be denied the privilege of engaging in the business.

From 1922 to 1929 the business grew from ror offices with loans of $\$ 3,778,356$, to 415 offices with loans of $\$ 20,549,35$ r. The greatest increase was during the two-year period ending November 30 , I928, when the number of offices increased from 263 to 437 and the outstanding balances from $\$ 9 ; 722,234$ to $\$ 19,001,151$. This increașe was precipitated by the flotation of securities, through radio advertising, by companies entering the small loan business. In order to obtain the large commission on security sales, promoters and agents made fantastic representations concerning lucrative returns possible under the $3 \%$ per month rate and the safety of investments in such enterprises because they were supervised by the State Banking Department. The large influx of capital led to unethical lending practices, overextension of eredit, and other extremes resulting in several receiverships and losses to investors.

These and many of the other excesses that crept into the business were practices over which the statute provided no control. It must be stated, however, that the small loan law did accomplish the primary purposes for which it was enacted, namely, the attraction of capital under regulation and the eradication of illegal and unconscionable lending.

In 1929 a legislative investigation brought about a reduction in the rate of charge from $3 \%$ per month to $1 \frac{1}{2} \%$ per month and a consequent withdrawal from the business of many independent and most interstate chain licensees. By November 30 , I93I, the number of offices had declined to II7 with outstanding loans of \$5,399,3II, and many of these offices were in the process of orderly liquidation.

At this time the Commissioner of Banking and Insurance created the Division of Personal Loan Agencies and authorized it to study the necessity for a small loan business, the need for a broader and more rigid law, the returns on investment of the then operating licensees and the desirability of an increased rate. The recommendations of the Commissioner to the newly created legislative committee studying the necessity for the small loan business and agitation for rate-increases led to the enactment, in April 1932, of a new small loan act patterned after the Fifth Draft of the Uniform Small Loan Law. The new act, among other innovations, conferred on the Commissioner discretionary powers in issuing licenses and also set minimum requirements as to assets and net worth. 


\section{Licensing of Applicants}

Realizing that many of the excesses in the business were due to unfair and unethical competition and recognizing that small loans were being overextended and should be controlled to prevent the reoccurrence of such practices, the State Banking Department decided to interpret strictly the discretionary license provision of the new law. This provision required of the Commissioner a finding-"That allowing the applicant to engage in the business would promote the convenience and advantage of the community." To do this it was essential that some plan of measuring the small loan capacity of each community be established.

From census bulletins the possible number of borrowers in our state was ascertained.- Our past statistical records revealed the actual number of persons borrowing and the average outstanding loan. Based on these facts, which were from the peak period in our small loan volume, a ratio of the actual number of borrowers to the possible number of borrowers was approximated. This ratio was then applied to the population of each community and a probable loan capacity set. When a locality approaches this maximum, or when the companies presently licensed have available funds to meet credit extensions of this amount, no further licenses are issued.

To protect further our borrowing public, who, because of the large withdrawal of loan capital by interstate chains when the rate was reduced in 1930, were left without adequate service, we today favor the licensing of companies composed of domestic interests because capital invested by local interests cannot easily be diverted from the industry without serious loss.

No foreign unit is permitted to make formal application until it has filed with the Division of Personal Loan Agencies an extensive questionnaire giving the complete history of the corporation or group applying, full disclosure of the methods used and the cost of acquiring its capital, the qualifications, experience and training of its officials, nature and type of its past and present operations, statements of financial condition, earnings and dividend records and complete information as to its credit possibilities. Verification of its experience and operations are confirmed through supervisory officials in other states.

It is believed that this restriction has contributed to the elimination of unethical business practices, unfair competition, overextension of credit; and has a tendency to

\begin{tabular}{|c|c|c|c|c|}
\hline \multirow{2}{*}{$\begin{array}{c}\text { Size of office } \\
\text { Used and useful assets }\end{array}$} & \multicolumn{2}{|c|}{$r 929$} & \multicolumn{2}{|c|}{1939} \\
\hline & $\begin{array}{l}\text { No. of } \\
\text { offices }\end{array}$ & $\%$ & $\begin{array}{l}\text { No. af } \\
\text { offices }\end{array}$ & $\%$ \\
\hline$\$ 25,000.00$ or less & 193 & 46.51 & 5 & $4 \cdot 31$ \\
\hline$\$ 25,000.01$ to $\$ 50,000.00$ & 84 & 20.24 & I6 & 13.79 \\
\hline$\$ 50,000.01$ to $\$ 100,000.00$ & $7 \mathrm{I}$ & 17.11 & 25 & $2 \mathrm{x} .55$ \\
\hline$\$ 100,000.01$ to $\$ 200,000.00$ & 43 & 10.36 & 33 & 28.45 \\
\hline$\$ 200,000.01$ and upward $\ldots \ldots \ldots \ldots$ & I4 & 3.37 & 37 & 31.90 \\
\hline$\ldots \ldots \ldots \ldots \ldots \ldots \ldots \ldots$ & Io & $2.4 \mathrm{I}$ & $\therefore$ & ... \\
\hline & 415 & 100.00 & 116 & 100.00 \\
\hline
\end{tabular}


increase efficiency, reduce costs of operation and thereby encourage voluntary rate reduction which, after all, is most beneficial to the borrowing public's welfare. This policy of limitation has in no way retarded the growth of the industry. On December 3I, 1939, there was outstanding in loans receivable the sum of $\$ 18,197,593$ compared with $\$ 20,549,35$ I in 1929 , the peak year. The size of the individual office today is much larger than in $1929^{\circ}$

\section{Enforcement of Law As Applied to Licensees.}

The small loan law confers certain privileges and imposes certain restrictions on licensees. In addition to these statutory provisions the Commissioner may prescribe additional rules and regulations. The regulations are issued to implement the mechanics of the law, prescribing the keeping of records, form of advertising, term of contract, filing of loan papers and conditions under which transfer of location may be made. Licensees are not permitted to move from the area in which they were licensed and not more than one licensee may be licensed at the same address The purpose of these latter regulations is to spread the loan service, protect licensees at their established locations and curtail the bartering of licenses.

Examinations are made annually by the Division's own staff. These examinations include a statement of the financial condition of each office, the results of its operations, analysis of its lending activities, careful checking to find violations of the statutory provisions, ample tests of interest calculations, analysis of collection policy, review of renewals and extensions. Reports of examinations are reviewed carefully and a letter commenting on the findings of the examiner are forwarded to each licensee with a copy of the report. If the findings disclose objectionable lending conditions, whether in violation of the statute or not, the responsible operating officials are required to attend a hearing to discuss the results and give definite assurance of their correction or elimination.

Besides the annual examination, detailed reports of operations are filed at the close of each calendar year, on the standard report form adopted by the National Conference of State Small Loan Supervisors. These reports are checked in detail, analyzed and compiled. An analysis of all loans refunded during the reporting year is also required for the purpose of ascertaining how many and how long borrowers remain indebted to licensees. Due consideration of these factors enables the Department to review more effectively the problems of the lenders and the public and to make recommendations that will prove beneficial to both.

Each licensee is required to file notice immediately upon the commencement of any summary action whether it be suit or repossession. If the number of such actions is large, special visits are made to the licensed office and the history of each case is carefully reviewed. Collection policies requiring numerous legal actions often disclose bad lending policies, overextensions of credit, lack of credit investigation and analysis, and if any of these factors are disclosed, a frank discussion with the companies' executives generally leads to a better social approach to the borrowers' problems. 
Complaints are given prompt and courteous treatment and immediate investigations are conducted. Where chain offices are involved, letters are directed to the head supervisor with a request for an independent check by his office and a detailed report. Many of these complaints are the result of collection pressure and while it is true that the licensee seldom exceeds his legal privilege, it often happens that he has overlooked or is unaware of the borrowers' problem. In such cases, after reviewing the reports of the companies' supervisory staff and our investigator, a conference is held with the licensee's home office representative and the borrower, tending toward an understanding of the problem by each party. Although we participate in the hearings, we prefer that all differences be adjusted between the parties themselves.

\section{Enforcement of Law As Applied to Non-Licensees.}

Today there are very few problems of unlicensed operation in New Jersey. This, we believe, is due primarily to strict and aggressive enforcement by the Department and to the assistance rendered by licensees in policing their own business. A practice is made of impressing upon each new licensee that his authority to engage in the business is a privilege that carries responsibilities to his community and that foremost among these is the eradication of illegal lending. His cooperation consists of reporting to our office any information about illegal lending by forwarding advertisements of unlicensed lending services appearing in newspapers or other printed matter, or knowledge of such unlicensed lending activities gained through refunding loan contracts.

When the information is a direct complaint, an investigator interviews the writer at once and obtains an affidavit of all the facts surrounding the transaction. Additional leads are then sought from records of suit instituted by the offender, records of filing of chattel mortgages or conditional bills of sale from information obtained from the records of the Motor Vehicle Department. (New Jersey requires that all changes in title to automobiles must be filed in the office of the Department of Motor Vehicles on its bill of sale forms.) These individuals are then visited and interrogated about their dealings with the offender.

Before proceeding against any non-licensed lender, we must show definite proof that he has engaged in the business of lending in violation of the act. This requires affidavits from two or more borrowers. When a case has been completed this information is then presented through the local county prosecutor to the grand jury and indictment sought. Once an indictment is handed down, little trouble is experienced in eliminating the practice.

Our experience with this procedure has not always been satisfactory, however, particularly in the case of auto lenders. We have found that they will discontinue their operations only to reopen in other areas under different corporate entities. This necessitates the development of new evidence and a new action to eliminate the offender. We have carefully considered this matter and believe that the small loan statute should confer upon the licensing official the power to apply direct to the courts 
for an injunction directing the production of records and enjoining further engaging in such operations.

\section{Protection of the Interests and Welfare of the Borrowers.}

The latest drafts of the Uniform Law contain ample protection to each and every borrower, but nevertheless there arise from all lending transactions problems which no law nor any regulation can prevent. These problems deal with the intent and spirit of these remedial statutes and can be solved only by a proper application of education toward true social objectives.

Most persons who, of necessity, must patronize the small loan lender; do so because of lack of collateral other than their character and future earning capacity. Their fulfillment of these obligations depends upon the permanency of their employment and their fortunate escape from the ills of life. These latter are the general contributory causes of delinquency in payment and in turn lead to the persistent collection policies adopted by many lenders. To cope with these problems, the supervisor, without sanction of statute or judicial precedent, must establish policies, based solely on social ethics, with reference to those practices which experience and interpretation of reports show to be detrimental to the industry and the welfare of the borrowing public. To enforce these unwritten policies the supervisor must rely on his ability to prove, by persuasion, that the practices are detrimental to the welfare of the industry and the borrowing public.

There should be an endeavor to have all licensees render a full loan service. The statute; having set a maximum rate, anticipates that it provides sufficient leeway to make loans in all sizes even though studies based on analysis of cost show prohibitive rates for the small-sized loan. These cost figures are based upon the assumption that only one-size loan is made and make no allowance for the average-sized loan made. While it is true that loans of small amount when considered per se are unprofitable, many other factors must be considered. The personnel of each office has a maximum capacity of handling so many accounts per employee per month and its most efficient and profitable results are obtained when operating at this capacity. Large sums are spent annually to introduce the service to the public and cash balances drawing little or no return are idle. Considering these points then, the rendering of a full small loan service instead of being unprofitable utilizes, apparently without increased cost, normally idle cash balances, reflects the greater productivity of advertising and employs to its maximum capacity the services of its personnel and offers to the citizens of the community the type of service it was licensed to provide. The client adequately serviced even for a small loan is always a prospective future client. $\mathrm{He}$ helps create that intangible though valuable asset, good will. 'To deny a worthy applicant this service is to destroy the effect of carefully planned salesmanship, to increase the dollar cost per loan and has a tendency to compel such persons to patronize the illegal lender from whom such lenders were organized and licensed to protect him. 
Another of the industry's great problems is the ultimate cost to the borrower. It is generally acknowledged that in actual dollars and cents, small loan borrowing costs are expensive. This, of necessity, must be so. When loans are paid according to contract, the total cost creates no social problem; however, delinquency over long periods of time is sure to create reactions against such lending. Most persons realize this, particularly social agencies whose duties bring them in daily contact with families in dire financial straits due to consumer debt burdens.

The National Conference of State Small Loan Supervisors, through its members, the small loan supervisors in their respective states, has attempted to curtail overlending by limiting the contract period of loans to 20 months. In New Jersey we permit loans to be made for no longer than 5 months, repayable in equal instalments. No balloon payments may be contracted for. Even with such restrictions, however, large interest accumulations continued until adequate steps were taken to limit the period over which the contract rate may be collected. Many states have gone so far as to amend their acts to limit this period by law.

While favoring the restriction of interest costs, we feel that statutory limitation is not the correct procedure. Rather, it should be approached through the power of regulation, because interest limitation is too closely interwoven with the practice of renewals and the statutory provision may thus be evaded.

Until 1935 little statistical information was available about renewals although the major chain lenders had statistics on their own businesses. In that year it was decided to attempt a study of renewals and licensees were directed to keep in permanent form a summary by period of contract of all loans renewed. The individual account cards in each office must show the date and amount of each original loan as well as the number of contracts currently made since the original. From this information it is now possible to ascertain the length of time each borrower has been consistently on the lenders' books. Annually, reports containing this information are filed with the Department. Renewals are classified in three groups:

Accounts renewed with additional cash advances.

Accounts renewed for balance only.

Accounts renewed for settlement in which some part of the interest or principal is waived.

During the year ending December 3r, r939, licensed lenders granted 243,598 loans totalling $\$ 37,924,846.9 \mathrm{r}$; of these, 149,564 loans were renewals, or $61.39 \%$. Of these 148,787 loans were renewed with increased balances, the average increase per account being \$r. So long as the additional cash advanced borrowers continues at such a high figure, no attempt should be made to curtail this form of service since it might bring hardships upon the very group of individuals in whose behalf our regulatory laws have been enacted.

It is with the second class of renewal, those made to reduce payments or extend the period of the contract that we are at present vitally concerned. Here supervisors can control interest costs and contract rate limitations. Following the failure of legislative attempts to regulaite the period over which the contract rate might be collected, 
the Department adopted a policy in which it advocated that all licensees agree to collect interest at the contract rate for a period of 21 months only. At the same time each lender was requested to discontinue making new contracts merely for the purpose of renewing existing balances. Each report of examination now contains a list of all open accounts aged 21 months or over, and a list of all accounis renewed for balance during the period of the examination.

The utmost cooperation has been received from all licensees although in the early stages it required persistent discussion to sell the idea. The surveys made by our examiners have proved valuable from an audit viewpoint because we have pointed out to the home offices of many chains that through renewal of balances, often forced by loan office managers, slow and worthless accounts have been removed from delinquent lists and thus considered current assets.

No objection is made to the alleviation of the contract terms in favor of the borrower. However, such changes must be made without refunding the account. In this manner we keep all such accounts open under the original loan date and they, therefore, appear on our 21-month list. When considered together with our original limitation of loan to contract periods of 15 months, we believe we have thus curtailed excessive credit extensions, collecting of interest only on accounts and have contributed largely to a reduction in delinquencies and collection costs. 